\title{
WHY EUROPE SHOULD RECONSIDER ITS ANTI-ARBITRATION POLICY IN INVESTMENT DISPUTES
}

\author{
Alan Uzelac \\ Prof. Dr., Full Professor of Law, \\ Head of Department for Civil Procedure, \\ Faculty of Law, University of Zagreb \\ (Zagreb, Croatia)
}

https://doi.org/10.33327/AJEE-18-2.1-a000008

\begin{abstract}
Summary: 1. Introduction. - 2. Moving away from arbitration and towards 'investment courts' in investor-state disputes. - 3. The Achmea case: a further blow to the popularity and use of arbitration in Europe. - 4. Follow-up: the aftermath of the Achmea case. - 5. Arguments behind the current European anti-arbitration stance. - 6. Are proposed alternatives an adequate reply to the weaknesses of investor-state arbitration? - 7. Conclusion
\end{abstract}

This paper addresses the current challenges to investor-state arbitration in Europe. Two parallel developments are outlined: the current change in the EU policy towards arbitration provisions in multilateral and bilateral investment treaties, and the consequences of the Achmea case decided by the Court of Justice of the European Union in March 2018. The author analyses the critical arguments behind the current European anti-arbitration stance and concludes that while some of them (but not all) may have some foundation, a sufficient number of reasons speak against the radical dismantling of the system of international investment arbitration. An analysis of the proposed alternatives shows that they fail to deliver viable solutions for diagnosed problems. In particular, the replacement of ad hoc tribunals by a multilateral investment court (MIC) seems to be a step in the wrong direction. The ISDS has played an important role in the global fostering of international investment by securing a basically fair system of dispute resolution in a very specific field. Its deficiencies are not beyond repair; on the other hand, the alternatives offered suffer from flaws that are the same or much more troubling. The author concludes that the consequences of the 'change of tide' in the approach to investor-state dispute resolution are likely to be detrimental to the very goals of those who advocate the abandoning of investment arbitration. 
Keywords: investor-state arbitration, European Union, multilateral investment court, ISDS, Achmea case, CJEU, NAFTA, USMCA, TTIP

\section{INTRODUCTION}

Today, the use of international commercial arbitration as a means of resolving international commercial disputes has reached an unprecedented level. However, while arbitration was progressing from an alternative to an almost standard dispute resolution mechanism for solving complex international disputes, new challenges which may turn the tide started to evolve. In this paper I will briefly present the current state of affairs regarding challenges to investor-state arbitration in Europe. Two topics discussed herein deal with two different but complementary developments: the new policy of the European Commission to move away from arbitration in investor-state disputes under international trade treaties, and the aftermath of the decision of the Court of Justice of the European Union (CJEU) in the Achmea case in which the Court found that investor-state dispute settlement system (ISDS) clauses in bilateral investment treaties violate European law. After an analysis of these developments, I will evaluate criticisms of the ISDS and suggest the reasons why alternative proposals do not meet the desired standards of quality and efficiency. My conclusion is that the current anti-arbitration wave in Europe should be moderated and partly reconsidered to avoid adverse consequences for international dispute settlement and international trade.

\section{MOVING AWAY FROM ARBITRATION AND TOWARDS 'INVESTMENT COURTS' IN INVESTOR-STATE DISPUTES}

The conventional concept of investment arbitration or ISDS is well known, so for the purposes of this paper I will give only a short summary of its main features. ${ }^{1}$ Treaties on protection of foreign investments often include a system of dispute resolution which allows that, in case of a dispute between the foreign investor and the state in which the investment was made, a dispute may be submitted to the forum selected by the claimant, who is most often the investor. This form of arbitration is based on the text of the treaty and does not need a pre-existing arbitration agreement between the investor and the state. ${ }^{2}$ Standard options that can be selected always involve arbitration under the UNCITRAL Rules, or certain institutional arbitration rules. The most prominent multilateral treaty which provides for ISDS is the ICSID Convention (also referred to as the Washington Convention) of

$1 \quad$ For more on investment arbitration see C McLachlan, L Shore, M Weininger, International Investment Arbitration. Substantive Principles (Oxford UP 2007); C Dugan, D Wallace, N Rubins, B Sabahi, Investor-State Arbitration (Oxford UP 2008); RD Bishop, J Crawford, W Reisman, Foreign Investment Disputes: Cases, Materials and Commentary (Kluwer 2005).

2 On the concept of treaty-based arbitration see J Paulsson, 'Arbitration Without Privity' (1995) 10

(2) ICSID Review - Foreign Investment Law Journal 232-257. 
1966, ratified globally by 154 countries. ${ }^{3}$ The convention established the International Centre for Settlement of Investment Disputes (ICSID) which provides facilities for arbitrations between the foreign investors and the member states of the convention.

A good example of ISDS in multilateral treaties is Chapter 11 of the North American Free Trade Agreement (NAFTA). ${ }^{4}$ The agreement has been in existence since 1994 and will continue to be in force until the coming into force of the latest US-Mexico-Canada agreement (USMCA) concluded in 2018. ${ }^{5}$ NAFTA Chapter 11 allows investors of one NAFTA party (Canada, the United States or Mexico) to bring claims directly against the government of another NAFTA party before an international arbitral tribunal, excluding thereby jurisdiction of local courts in any of the three countries. ${ }^{6}$

The arbitration-friendly position in NAFTA (which, however, is changing, see below) is typical for the pro-investment climate of the late 1980s and early 1990s, when over 3,000 international instruments, including a number of bilateral investment treaties (BITs), were concluded. ${ }^{7}$ All of them, just like NAFTA, allowed for a treaty-based arbitration as 'a mechanism for the settlement of investment disputes that assures both equal treatment among investors of the Parties in accordance with the principle of international reciprocity and due process before an impartial tribunal. ${ }^{8}$ Under investment treaty arbitration provisions, the host governments would automatically give consent to be sued by foreign investors for violation of a number of substantive rights enumerated in such treaties, for instance the prohibition of expropriation or violation of the standard of fair and equitable treatment.

However, after a massive wave of investor claims raised in the late 1990s, the climate changed.' As soon as it showed its effectiveness, the 'emerging global

3 Convention on the Settlement of Investment Disputes between States and Nationals of Other States, enacted by the International Bank for Reconstruction and Development (the World Bank) in 1965 and entered into force on 14 October 1966. See more in L Reed, J Paulsson, N Blackaby, Guide to ICSID Arbitration (Kluwer 2004); C Schreuer, The ICSID Convention: A Commentary (Cambridge UP 2009).

4 On NAFTA Arbitration see F Bachand (ed), Fifteen Years of NAFTA, Chapter 11: Arbitration (Juris 2011); T Weiler, NAFTA Investment Law and Arbitration: Past Issues, Current Practice, Future Prospects (Transnational Publishers 2004). See also <https://www.international.gc.ca/trade-agreementsaccords-commerciaux/topics-domaines/disp-diff/nafta.aspx > accessed 21 February 2019.

5 Compare materials at $<$ https://ustr.gov/trade-agreements/free-trade-agreements/united-statesmexico-canada-agreement $>$ accessed 21 February 2019.

6 See Arts 1115-1120 of NAFTA. Options for the investor are to submit a claim either under the ICSID Convention (or the Additional Facility Rules of ICSID) or the UNCITRAL Arbitration Rules.

7 Almost half of the total number of these instruments were concluded by EU Member States. See A Henke, 'Report on desirability of the investment arbitration in the context of TTIP negotiations (Wiesbaden ELI SIG Meeting on ISDS, 19-20 February 2016).

8 Art 1115 NAFTA.

9 According to UN-collected data, in 1998 the global number of treaty-based ISDS cases initiated in a year was for the first time (and continually afterwards) more than 10; the largest annual number was 80 in 2015. Up to the end of 2017 there were 855 known ISDS cases. In 2017, 65 new cases were reported; the amount in dispute (according to information from about one-quarter of the cases) ranged from US $\$ 15$ million to US $\$ 1.5$ billion. See UNCTAD, 'Investor-State Dispute Settlement: Review of Developments in 2017' (2018) 2 IIA Issues Note p 2 and 4. 
regime for investment' elaborated in thousands of international instruments started to face major challenges. ${ }^{10}$ The European Union joined the anti-ISDS movement, which was labelled the 'backlash against investment arbitration. ${ }^{11}$ This position was most obviously taken by the European Union in the context of negotiations regarding the EU-US trade agreement, the notorious Transatlantic Trade and Investment Partnership (TTIP), which turned out to be among the most controversial treaty projects on trade ever conceived by either of the two sides of the Atlantic. ${ }^{12}$

One stepping stone in the TTIP negotiations, which started in July 2013, was the investor-state dispute settlement system. ${ }^{13}$ At the beginning of the negotiations, many European politicians and NGOs moved against inclusion of ISDS in the treaty. ${ }^{14}$ Some European governments procured studies on the impact of ISDS in international treaties. ${ }^{15}$ Other studies suggested that there was little evidence on the meaningful benefits that investor-state arbitration could provide to the EU, and that its collateral effects might impose non-trivial costs for the European states. ${ }^{16}$ The European Parliament voiced support only for a state-to-state dispute settlement system and opposed any bypassing of national courts. ${ }^{17}$ After online public consultations conducted in 2014, ${ }^{18}$ in its 2015 concept paper the European

10 See JW Salacuse, 'The Emerging Global Regime for Investment' (2010) 51 Harvard International Law Journal, 427-473..

11 Compare M Waibel, A Kaushal, A Liz Chung, C Balchin, The Backlash against Investment Arbitration. Perceptions and Reality (Wolters Kluwer 2010).

12 See more on the evolution of European views on ISDS in W Hummer, 'Was haben TTIP, CETA und TISA gemeinsam? "Investor-To-State Dispute Settlement" (ISDS) als umstrittenes Element der EU-Freihandelsabkommen' (2015) 38(1) Integration 3-25; see also N Lavranos, 'The Impact of EU Law on ISDS' in D Roughton, K Beale (eds), The International Comparative Legal Guide to Investor-State Arbitration 2019 (GLG 2018) 41-44.

13 On endorsing the project of TTIP in 2013 see <http://europa.eu/rapid/press-release_MEMO-13564_en.htm> accessed 21 February 2019. See also <http://ec.europa.eu/trade/policy/countriesand-regions/countries/united-states/> accessed 21 February 2019 (on EU-US trade negotiations in general) and <http://ec.europa.eu/trade/policy/in-focus/ttip/> accessed 21 February 2019 (official EU site on TTIP negotiations).

14 For a summary of political discussions see EurActiv 'TTIP and the Arbitration Clause' (Special Report, 8-12 December 2014) <http://www.euractiv.com/sections/ttip-and-arbitrationclause >accessed 21 February 2019.

15 See eg the study prepared for the Dutch Foreign Ministry: C Tietje, F Baetens, 'The Impact of Investor-State-Dispute Settlement (ISDS) in the Transatlantic Trade and Investment Partnership' (Study prepared for Minister for Foreign Trade and Development Cooperation, Ministry of Foreign Affairs, The Netherlands, MINBUZA-2014.78850) <https://www.eumonitor.eu.> accessed 21 February 2019..

16 Compare L Poulsen, J Bonnitcha, J Yackee, 'Transatlantic Investment Treaty Protection' (Paper No 3 in the CEPS-CTR Project on 'TTIP in the Balance' and CEPS Special Report No 102, March 2015).

17 See European Parliament resolution of 8 July 2015 containing the European Parliament's recommendations to the European Commission on the negotiations for the Transatlantic Trade and Investment Partnership (TTIP), recommendation 2(c)(xv).

18 For a report on this public poll see European Commission, 'Online Public Consultation on Investment Protection and Investor to state Dispute Settlement (ISDS) in the Transatlantic Trade and Investment Partnership Agreement (TTIP)', (SWD 2015, 3 final, Brussels 13 January 2015) <http://trade.ec.europa.eu/doclib/docs/2015/january/tradoc_153044.pdf> accessed 21 February 2019. The EU claims that about 150,000 replies were received during the consultations. 
Commission finally announced that it was moving from 'current ad hoc arbitration towards an Investment Court. ${ }^{19}$

In the next stage of negotiations, the draft text of the TTIP proposed by the EU excluded ISDS provisions and included provisions on a special, hybrid body for investor-state dispute resolution - a standing investment tribunal that would be established under the treaty once it came into effect. ${ }^{20}$ The only traces of arbitration which remained in this draft were visible in the rules on recognition and enforcement of foreign 'arbitral awards' (inter alia, by the reference to the New York Convention). ${ }^{21}$

In the end, the Transatlantic Treaty negotiations discontinued, but for a different reason: the hostile position of the current US administration towards multilateral trade treaties. However, while TTIP - at least at this moment - seemed to be a failed project, in the meantime another instrument for the protection of trade and foreign investments was adopted, the EU trade agreement with Canada, better known as CETA (Comprehensive Economic and Trade Agreement). ${ }^{22}$

In CETA, the policy of moving away from arbitration materialised in its dispute resolution provisions, which are based on a new investment court system. The EU advertised this system as a 'replacement of the ISDS' by 'a new and better' system. This system, according to official announcements, enshrines the right of governments to regulate in the public interest, but also introduces a system which is public, professional, and transparent. ${ }^{23}$

From the text of CETA ${ }^{24}$ it is obvious that the 'permanent dispute settlement tribunal' provided by the agreement is everything but an arbitral body. It is composed of judges appointed by the two state parties (the EU and Canada) and does not allow the typical features of arbitration such as party-driven selection of adjudicators (in particular by the investors), exclusion of appeals and autonomy in the selection of the applicable

19 See 'EU Commission Concept Paper Investment in TTIP and beyond - the path for reform' $<$ http://trade.ec.europa.eu/doclib/html/153408.htm> accessed 21 February 2019. See also 'Commission proposes new Investment Court System for TTIP and other EU trade and investment negotiations'<http://europa.eu/rapid/press-release_IP-15-5651_en.htm> accessed 21 February 2019.

20 On this proposal see 'EU finalises proposal for investment protection and Court System for TTIP' $<$ http://europa.eu/rapid/press-release_IP-15-6059_en.htm> accessed 21 February 2019.

21 Latest Commission draft of investment protection provisions of the TTIP, see <http://trade. ec.europa.eu/doclib/html/153807.htm> accessed 21 February 2019.

22 See 'EU-Canada: Comprehensive Economic and Trade Agreement (CETA)' <http://ec.europa. eu/trade/policy/in-focus/ceta/> accessed 21 February 2019. The consolidated text of CETA is available at <http://trade.ec.europa.eu/doclib/docs/2014/september/tradoc_152806.pdf> accessed 21 February 2019. The CETA entered provisionally into force on 21 September 2017. The national parliaments of all EU countries need to take action before CETA can take full effect (as of January 2019 only about half of all EU Member States had notified their accession; see <https://www.consilium.europa.eu/en/documents-publications/treaties-agreements/ agreement/?id=2016017> accessed 21 February 2019.

23 'CETA Explained' <http://ec.europa.eu/trade/policy/in-focus/ceta/ceta-explained/index_ en.htm> accessed 21 February 2019.

Arts 8.18-8.45 CETA. 
law and procedure ${ }^{25}$ Moreover, it is clear that the policy of avoiding arbitration as a means of resolving investment disputes is not meant to be limited to particular trade agreements. In Article 8.29 of CETA, Europe and Canada commit to 'pursue with other trading partners the establishment of a multilateral investment tribunal and appellate mechanism for the resolution of investment disputes'. This confirms that rejection of arbitration options will be an element of future policies in international investment treaties that are concluded both by the EU and by Canada.

In the meantime, the EU either has signed or is negotiating a number of trade agreements with countries and regions around the world. These include trade agreements with Japan, Vietnam, New Zealand, Australia, Singapore and Mexico, as well as the EU-Mercosur trade agreement that includes the four South American states Argentina, Brazil, Paraguay and Uruguay. ${ }^{26}$ In most of these concluded or contemplated agreements, ${ }^{27}$ some forms of dispute resolution mechanisms are envisaged, with a tendency to have less and less reference to any form of proper international arbitration.

Europe is not alone in its suspicious attitude towards investment arbitration. On the other side of the Atlantic, the rejection of ISDS has already been confirmed in the agreement that will replace NAFTA and its Chapter 11 ISDS mechanism. Namely, under the USMCA ${ }^{28}$ the US investors in Canada and Canadian investors in the United States will only find recourse in national courts. ${ }^{29}$ In US-Mexico investment disputes, claimants will continue to have the right to submit a claim to arbitration alternatively under the ICSID Convention and Additional Facility Rules or under the UNCITRAL Arbitration Rules. ${ }^{30}$ Interestingly, Canadian investors in Mexico and Mexican investor in Canada seem to be, under the current text, authorised to initiate investment arbitration under another multilateral treaty, the TransPacific Treaty (CCTPP) which has still not been ratified by the required number of signatories (but will certainly not be ratified by the United States, at least not under its current administration). ${ }^{31}$ This, as described in the next section, is much

25 On other features of CETA dispute resolution see L Pantaleo, 'Investment Disputes Under CETA. Taking the Best from Past Experience?' (February 27, 2016) <https://ssrn.com/abstract=2739128 or http://dx.doi.org/10.2139/ssrn.2739128> accessed 21 February 2019.

26 See European Commission 'Negotiations and agreements' <http://ec.europa.eu/trade/policy/ countries-and-regions/negotiations-and-agreements/> accessed 21 Februar 2019.

27 One of the trade agreements currently negotiated is TISA (Trade in Services Agreement) where the issue of ISDS also proved to be controversial. See 'Trade in Services Agreement (TiSA)' $<$ http://ec.europa.eu/trade/policy/in-focus/tisa/> accessed 21 February 2019.

28 See Chapter 14 on investment, <https://ustr.gov/sites/default/files/files/agreements/FTA/ USMCA/Text/14_Investment.pdf> accessed 21 February 2019.

29 See 'USMCA Scales Back on Investor-State Arbitration but Preserves Trade Dispute Resolution in North America', <https://www.lexology.com/library/detail.aspx?g=44d1dcd0-8f81-4fea-a023cd6706d33933> accessed 21 February 2019. Eventually, arbitration may be conducted, but only as state-to-state arbitration under Chapter 31 USMCA.

30 See Art 14-D USMCA (Mexico-United States Investment Disputes).

31 Anyway, there is still some good news for investment arbitration under the USMCA. Namely, its provisional regime allows for continuation of ISDS for at least three more years. In other words, existing arbitrations under NAFTA will remain unaffected, but it will also be possible to initiate new arbitrations even when NAFTA ceases to be in force, since the old NAFTA system of ISDS will remain available for three years after NAFTA's termination for protection of those investments that were made in the period during its validity. 
more favourable for continuation of investment arbitration compared to the present situation in Europe after the Achmea judgment.

\section{THE ACHMEA CASE: A FURTHER BLOW TO THE POPULARITY AND USE OF ARBITRATION IN EUROPE}

The trend of anti-arbitration actions by the bodies of the European Union continued also in 2018. This time, the blow to arbitration was not caused by the executive bodies of the EU, but by its judicial branch. In March 2018, the CJEU issued a decision in a case initiated by the highest German court, the Federal Court of Justice (BGH), which had submitted a request for a preliminary ruling in proceedings between the Slovak Republic and the Dutch company Achmea BV. ${ }^{32}$

The request for a preliminary ruling, dealing with the validity of the arbitration conducted between the Dutch investor and the Slovak state, at first looked like a pure formality. All the tribunals and courts which participated in this process, including the BGH itself, held the same position; thus, most of the observers were of the opinion that the CJEU would follow this position and routinely confirm the validity of the arbitral award made against Slovakia, thereby only restating the customary position on ISDS. The same could be forecast based on the opinion delivered in this case by Advocate General Wathelet, on 19 September 2017, who shared the same line of reasoning and found no incompatibility of this ISDS arbitration with EU law. ${ }^{33}$ Therefore, everyone was caught by surprise when the judgment of the Court reversing the position of its AG was published.

Before turning to the reasoning of the CJEU, a brief recapitulation of the facts in the Achmea case is in order. The request submitted to the CJEU concerned the case of enforcement of an arbitral award which was made 2012 in an arbitration conducted under the bilateral investment treaty (BIT) concluded in 1991 between the governments of the Netherlands and the (then) Czech and Slovak Federative Republic. The 1991 BIT (which continued to be applicable due to state succession as the Dutch-Slovak BIT) contained in its Article 8 a provision very common in many similar BITs. Under this provision, the investors from either side were entitled to initiate arbitration against the state in which the investment was made. The arbitration under this BIT was governed by the UNCITRAL Arbitration Rules.

Using the provisions of this BIT, a Dutch investor - the Dutch private health insurance company Achmea - brought in 2008 arbitration proceedings against the Slovak Republic. In 2012, this arbitration ended with an arbitral award in which the Slovak Republic was ordered to pay damages to Achmea in the amount of $€ 22.1$ million. Instead of paying this amount, the Slovak Republic launched the application for the setting aside of the award. Since the place of arbitration selected

32 Slovak Republic $v$ Achmea, C-284/16, judgment of the CJEU of 6 March 2018. See also the BGH request, decision of 3 March 2016, I ZB 2/15, ECLI:DE:BGH:2016:030316BIZB2.15.0. 
by the parties was Frankfurt, the application was decided by the German courts. The German courts rejected the application by the Slovak Republic both in the first instance proceedings, conducted before the Higher Regional Court (OLG) in Frankfurt, and, in principle, in the proceedings at the BGH, which held that the position of the Slovak state was not justified. ${ }^{34}$

The Slovak Republic argued that the arbitration court did not have the jurisdiction to decide the case since the arbitration clause in the Dutch-Slovak BIT was not in line with Articles 18, 267 and 344 of the Treaty on the Functioning of the European Union (TFEU). The German Federal Court made clear that it did not agree with this position, but for the avoidance of doubt referred the case to the CJEU. The Advocate General agreed with the BGH and opined in September 2017 that European law 'must be interpreted as not precluding the application of an investor/State dispute settlement mechanism established by means of a bilateral investment agreement concluded before the accession of one of the Contracting States to the European Union. ${ }^{35}$

But, in its judgment, the CJEU overruled its Advocate General and finally found that the arbitral provision from the Dutch-Slovak BIT (Art 8) has an adverse effect on the autonomy of EU law since the only bodies authorised to interpret EU law are EU bodies (and the Luxembourg Court itself). ${ }^{36}$ To that extent, the CJEU ruled that EU law precludes such agreements, which essentially means that the arbitration was concluded under a clause that is contrary to EU law, and from the perspective of EU law needs to be considered invalid. Reluctantly, such a position had to be adopted by the $\mathrm{BGH}$, which in turn finally concluded that the arbitral clauses contained in the 'intra-EU BITs' (bilateral treaties for protection of investments concluded between two EU Member States) are 'not applicable' (unanwendbar), thereby leading to the same consequences as if the arbitral agreement was inexistent or invalid. ${ }^{37}$

In short, from the Achmea decision of the CJEU it seems that all ISDS clauses allowing for investor-state arbitration contained in the BITs concluded between two Member States of the EU have to be viewed as contrary to EU law. If this is the case, then it is not only foreseeable that the awards issued in these arbitration proceedings can be annulled in setting aside proceedings, but it is also likely that such awards will not be recognised and enforced, at least if the place of enforcement is in a Member State of the EU.

$34 \quad$ See summary of facts in the Achmea judgment, (n 33) 6-14.

35 Opinion Wathelet (n 33)273.

36 The conclusion of the Court was that, Articles 267 and 344 TFEU must be interpreted as precluding a provision in an international agreement concluded between Member States, such as Article 8 of the Agreement on encouragement and reciprocal protection of investments between the Kingdom of the Netherlands and the Czech and Slovak Federative Republic, under which an investor from one of those Member States may, in the event of a dispute concerning investments in the other Member State, bring proceedings against the latter Member State before an arbitral tribunal whose jurisdiction that Member State has undertaken to accept.' Achmea, cit. at 62.

BGH, decision of 31 October 2018, I ZB 2/15, ECLI:DE:BGH:2018:311018BIZB2.15.0. 


\section{FOLLOW-UP: THE AFTERMATH OF THE ACHMEA CASE}

Since the Achmea decision, there have been no further reported court cases in which the arbitral awards made under intra-EU BITs arbitration provisions were finally set aside. However, some such cases are already pending where various European states, when ordered to pay the investors various sums under investment treaty claims, either objected to the jurisdiction of the arbitral tribunal or started setting aside proceedings based on the reasoning analogous to that in the Achmea decision.

The issues raised in several proceedings relate to the eventual broadening of the scope of the CJEU decision. Namely, in two such cases - Masdar v. Spain ${ }^{38}$ and Vattenfall v. Germany ${ }^{39}$ - the defendant EU Member States raised the Achmea arguments in arbitrations which were not based on the ISDS clauses in a bilateral treaty, but in a multilateral instrument, the Energy Charter Treaty (ECT).

In terms of importance and the scope of signatories, this treaty is much more important than the BITs, as it was concluded with the involvement of the United Nations and the World Trade Organization (WTO), and a number of other organisations too, and has been signed by some 50 countries as well as by the European Union itself. ${ }^{40}$ The treaty also gave rise to some of the most voluminous arbitral awards in the world, such as the award in the Yukos case in which damages in the amount of US\$50 billion were awarded against Russia in 2014, but due to non-ratification was later set aside in the Netherlands. ${ }^{41}$

In the Masdar case, Spain invoked the Achmea decision against a Dutch investor, and argued that the tribunal had no jurisdiction to act due to the violation of EU law. The reason for this was that both Spain and the Netherlands are EU Member States, and Spanish lawyers interpreted the Achmea decision in the sense that EU investors cannot bring investment treaty arbitration proceedings under an international agreement if the other side is also an EU Member State. This objection was rejected by the arbitrators in the arbitral proceedings. They concluded that the Achmea case literally relates only to the Dutch-Slovak BIT, and that - even if it were to apply to all intra-EU BITs - the ECT is not a bilateral treaty between EU Member States. It was also noted that the EU is itself a party to the ECT, which could indicate that it knew and accepted the ISDS provisions contained therein. ${ }^{42}$

38 Masdar Solar \& Wind Cooperatief U.A. $v$ Kingdom of Spain, ICSID Case No ARB/14/1.

39 Vattenfall $v$ Germany, ICSID Case No ARB/12/12.

40 On the ECT in general see more in T Wälde, The Energy Charter Treaty. An East-West Gatewey for Investment and Trade (Kluwer 1996); on the ECT ISDS see T Roe, M Happold, Settlement of Investment Disputes under the Energy Charter Treaty (Cambridge UP 2011). See also 'The Energy Charter Treaty' <https://energycharter.org/process/energy-charter-treaty-1994/energy-chartertreaty/> accessed 22 February 2019.

41 See B Knowles, K Moyeed, N Lamprou, 'Set Aside an Arbitral Award, Yukos' (Kluwer Blog, 13 May 2016) <http://arbitrationblog.kluwerarbitration.com/2016/05/13/the-us50-billion-yukos-awardoverturned-enforcement-becomes-a-game-of-russian-roulette/> accessed 22 February 2019; see also 'The Yukos Case' <https://www.yukoscase.com/news/> accessed 22 February 2019.

Masdar v Spain, 678-683. 
Similarly, Germany invoked the Achmea decision in the arbitral proceedings initiated by a Swedish nuclear energy investor Vattenfall. The decision of the arbitral tribunal presided over by Professor Albert Jan van den Berg in this ISCID case was the same - they concluded that the Achmea decision does not directly apply to the arbitrations arising out of multilateral treaties since, among other reasons, the rules of such treaties (in particular Art. 16 ECT) have to be interpreted as lex specialis in relationship to Article 351 of the TFEU. 43

The same avenue was taken in some other investment disputes, in particular in the recent decision of the arbitral tribunal at the Stockholm Chamber of Commerce (SCC) which affirmed its jurisdiction in the arbitration initiated on the basis of the ECT against two Luxembourg, two Italian and one Danish companies which made investments in Spain related to renewable energy legislation..$^{44}$ The tribunal found no carve-out from ECT protection provided under Article 26 which would relate to intra-EU disputes and concluded that EU law is not relevant to the issue of its jurisdiction. ${ }^{45}$

Indeed, whether or not this will be affirmed it will eventually be addressed by the CJEU in the near future. It is reported that Spain has already requested in the cited SCC proceedings that this issue be submitted to the CJEU, and similar pressure has been exerted by other EU countries which are involved in intra-EU investor-state arbitrations. One such case is the Croatian Gavrilović case decided by the ICSID dealing with the arbitration proceedings brought by an Austrian investor under an Austrian-Croatian BIT. ${ }^{46}$ Though this arbitration is based on an intra-EU BIT, the case was decided by the ICSID in Washington DC pursuant to the provisions of the 1965 Washington Convention. Therefore, it will be interesting to see how a number of occurring questions are treated in the future reasoning of the CJEU.

But, no matter whether this questioning of conformity with EU law will lead to further broadening of the scope of investor-state arbitrations considered to be invalid, the damage has already been done. Many arbitrations initiated on the basis of a presumably impeccable legal basis, ie on the basis of valid ratified international

43 The tribunal opined that, 'Article 16 poses an insurmountable obstacle to Respondent's argument that EU law prevails over the ECT. The application of Article 16 confirms the effectiveness of Article 26 and the Investor's right to dispute resolution, notwithstanding any less favourable terms under the EU Treaties. If the Contracting Parties to the ECT intended a different result, and in particular if they intended for EU law to prevail over the terms of the ECT for EU Member States, it would have been necessary to include explicit wording to that effect in the Treaty'. Vatenfall $v$ Germany, cit., Decision on the Achmea issue of 31 August 2018, 229.

44 See Foresight Luxembourg Solar 1 S.à.r.l., Foresight Luxembourg Solar 2 S.à.r.l., Greentech Energy Systems A/S, GWM Renewable Energy I S.P.A. and GWM Renewable Energy II S.P.A. $v$ The Kingdom of Spain, SCC Arbitration V (2015/150), award of 14 November 2018.

45 See K Hough, 'Achmea judgment analyzed and FET claim granted in ECT case against Spain' (21 December 2018) https://www.iisd.org/itn/2018/12/21/achmea-judgment-analyzed-and-fetclaim-granted-in-ect-case-against-spain-kirrin-hough/ accessed 22 February 2019.

46 See Gavrilović v Croatia, ICSID Case No ARB/12/39, award of 26 July 2018. In this case, Croatia expressly relied on Achmea in its request of 4 April 2018. It was rejected by the decision of the tribunal on 30 April 2018, mainly because the objection was not raised in due time. See the Decision at <https:/www.italaw.com/sites/default/files/case-documents/italaw9871.pdf> accessed 22 February 2019. 
agreements, face the prospect of being invalidated or not enforced. The final effect triggered by the CJEU in the Achmea case will be - in stark contrast to the approach in the case of NAFTA arbitrations which will be possible even after cancellation of the treaty - fundamentally retroactive in nature. In other words, a likely prospect in arbitrations which were initiated and, in some cases, concluded a long time ago may now be refusal of recognition and enforcement, especially if the EU Member State has an acute interest in refusing recognition. ${ }^{47}$

\section{ARGUMENTS BEHIND THE CURRENT EUROPEAN ANTI-ARBITRATION STANCE}

In a way, it seems that the investor-state arbitration was a victim of its own success. The backlash against arbitration in investor-state disputes originated with the boom in high-value investor-state arbitrations in which states were ordered to pay substantial sums to foreign investors. History shows that most states are open and benevolent when declaring high principles, but equally outraged when the same principles are applied to their actions and associated with sanctions, as showed by a similar backlash against the decisions of the international tribunals in other sensitive areas. ${ }^{48}$ Many capital-exporting countries, such as Canada or Germany, never thought that an ISDS case could be successfully initiated against them, relying on the idea that investment treaties awarded special protection to investors only in order to protect the companies from developed Western states from the unreliable justice systems in the developing world. ${ }^{49}$ But, the boom in investor-state cases in the 2000s showed that investments do not conform to the customary developed/

$47 \quad$ Another example of disrespect for finality of the arbitral awards, and of a retroactive application of EU law to investment arbitration, is the Micula case. In an ICSID arbitration based on a Romanian-Swedish BIT signed in 2003, an arbitral tribunal after eight years of arbitration issued an award in favour of claimants, awarding in December $2013 € 200$ million to the Micula brothers (see Ioan Micula, Viorel Micula, S.C. European Food S.A, S.C. Starmill S.R.L. and S.C. Multipack S.R.L. $v$ Romania, ICSID Case No. ARB/05/20). The dispute related to tax incentives given for investing in disadvantageous areas of Romania in early 2000. Due to Romanian accession to the European Union, the incentives were abolished in 2005 in order to comply with EU rules on prohibition of state aid. The final and binding award, on 369 pages, was issued in 2013, finding that Romania did not act unreasonably or in bad faith when it abolished the incentives, but that it still violated the claimants' legitimate expectations that incentives would be available until 2009 , in particular because the state did not inform the claimants in a timely manner that the regime would be terminated prior to its stated date of expiration, and by insisting nonetheless on further fulfilment of the claimants' obligations. Soon after the award was issued, in a letter from January 2014, the European Commission (which played an amicus curiae role in the arbitration) obliged Romania 'to suspend any action which may lead to the execution or implementation of the part of the Award that had not yet been paid, as such execution would constitute unlawful State aid'. Compare EC letter, C(2014) 6848 final (<https://www.italaw.com/sites/default/files/ case-documents/italaw4066.pdf > accessed 22 February 2019).

48 Compare KJ Alter, JT Gathii, LR Helfer, 'Backlash Against International Courts in West, East and Southern Africa: Causes and Consequences' (2016) 27 European Journal of International Law 293-328 which under the same title ('backlash') list three case studies related to various African states which attempted to restrict the jurisdiction of various international courts in response to politically controversial rulings.

49 Regarding the latter point see M Schneider, 'The Role of the State in Investor-State Arbitration. Introduction' in S Lalani, RP Lazo (eds), The Role of the State in Investor-State Arbitration (Martinus Nijhoff Publishers 2014) 4. 
developing divide, so not only the 'usual suspects', but also those states that like to view themselves as investors only started to appear as respondents before various arbitral fora, and that started to influence their attitude towards the ISDS..$^{50}$ The bigger the country, the stronger the resistance to defeat, as anecdotally proven by the fact that the United States have never lost a single ISDS case. ${ }^{51}$

While current criticisms voiced by EU authorities often accuse the ISDS of (anti-governmental) bias, it is interesting to recollect the history. Some evidence from particular investor-state arbitrations shows how (un)principled states have behaved in upholding the independence and impartiality of arbitrators when their own interests were at stake. Jan Paulsson tells us a story about the1903 Alaskan Boundary case in which President Theodore Roosevelt himself wrote 'personal and confidential instructions' to 'three impartial jurists of repute' selected as American arbitrators in the border case. ${ }^{52}$ One hundred years later, as showed again by Paulsson, the same attitude had spread to the area of investment arbitration. In the infamous Lowen case, the American arbitrator appointed to act in a NAFTA arbitration publicly admitted that he was under considerable political pressure, and that he had been summoned by governmental officials and warned that the state party which appointed him must prevail. ${ }^{53}$

The relative fairness of the ISDS mechanism may have been a reason for its unpopularity with some states unfamiliar with losing litigation in international fora. Ominously, it was not the withdrawal of Venezuela, Bolivia and Ecuador from the ICSID Convention that changed the ISDS landscape, but the change of policies in the United States, Canada and the EU.

On the other hand, there are indeed valid conceptual reasons for the current 'legitimacy crisis' in investment treaty arbitration. ${ }^{54}$ Here are a few prominent criticisms which deserve attention:

50 According to UNCTAD data, the most frequent respondent states in the 1987-2017 period were Argentina, Venezuela, Spain, the Czech Republic, Egypt, Canada, Mexico, Poland and India. At the same time, the most frequent home states of claimants were the United States, the Netherlands, the United Kingdom, Germany, Canada, France and Spain. While the divide between the capitalimporting and capital-exporting countries is still visible, some countries, eg Canada and Spain, occupy high places on both lists.

51 S Puig, G Schaffer, 'Imperfect Alternatives: Institutional Choice and the Reform of Investment Law' (2018) 112 American Journal of International Law 400.

52 J Paulsson, 'Moral Hazard in International Dispute Resolution' (2010) 25 (2) ICSID Review Foreign Investment Law Journal 341-343.

53 The arbitrator was warned that, 'If we [ie the USA] lose this case, we could lose NAFTA' and the arbitrator conformed to expectations. Ibid, 345-346. On the Lowen case see more in M Mendelson, 'The Runaway Train: The "Continuous Nationality Rule" from the Panevezyssaldutiskis Railway Case to Lowen' in T Weiler, International Investment Law and Arbitration: Leading Cases (Cameron May 2005) 97-149.

54 The notion of a 'legitimacy crisis' is used by Franck (SD Franck, 'The Legitimacy Crisis in Investment Treaty Arbitration: Privatizing Public International Law Through Inconsistent Decisions' (2005) 73 Fordham Law Review $1521<$ https://ssrn.com/abstract=812964> accessed 21 February 2019), though only related to a limited field of (in)consistency of decisions. On this matter, for a plausible opposite point of view (arguing that consistency is not possible or even desirable) see Schneider (n 49) 10. More recently on the legitimacy crisis see Ch 9 of J Bonnitcha, LNS Poulsen, M Waibel, The political economy of the investment treaty regime (Oxford UP 2017). 
1. The closed nature of the world of investment treaty arbitrations - excessive specialisation that creates a narrow field which is removed both from commercial arbitration and from public international law; ${ }^{55}$

2. An alleged lack of democratic accountability and lack of sensitivity to allegations of corruption; ${ }^{56}$

3. Lack of diversity, e.g. the dominance of male arbitrators and the lack of female arbitrators; ${ }^{57}$

4. Insufficient space for balancing the regulatory policies of the state against the interests of the private investors; ${ }^{58}$

5. Built-in bias in favour of investors, often connected with problems regarding the impartiality of arbitrators who appear in the role of counsels in other arbitrations (double-hatting) or with other forms of conflicts of interest; ${ }^{59}$

\section{Absence of transparency and appeal options; no uniform case law; ${ }^{60}$}

7. Lack of symmetry in procedure, forum shopping and possible parallel proceedings. ${ }^{61}$

The purpose of this paper is not to offer an extensive debate on the mentioned (or any other) potential deficiencies of the investment-state arbitrations. Rather, we will deal with these features within the discussion in the next section, where they will be put in the context of other, often equally imperfect alternatives.

\section{$55 \quad$ Schneider (n 49) 8.}

56 See A Ali, ES Romero, 'Arbitration of Corruption Allegations' in: The International Comparative Legal Guide to Investor-State Arbitration 2019 (GLG 2018) 10-14.

57 Compare K Polonskaya, 'Diversity in Investor-State Arbitration: Intersectionality Must Be a Part of the Conversation' (2018) 19(1) Melbourne Journal of International Law 259-298.; G Van Harten, 'The (Lack of) Women Arbitrators in Investment Treaty Arbitration' (2012) 59 Colum FDI Persps <https://academiccommons.columbia.edu/doi/10.7916/D8HT2XHM> accessed 21 February 2019.

58 See more in A Turyn, F Perez Aznar, 'Drawing the Limits of Free Transfer Provisions' in M Waibel, The Backlash Against Investment Arbitration: Perceptions and Reality (Kluwer 2010) 51-71. This reason also played a prominent role in the European Commission (EC) move against ISDS; see the EC Concept Paper (2015) where the EC noted the need to protect the EU's 'right to regulate' and the need to have ISDS options which 'do not affect the ability of the EU and its MS to pursue public policy objectives. The limitation of the state power to regulate was among the most common criticisms in a line of cases that dealt with regulatory measures in Canada (the Myers, Chemtura and Ethyl Corp. cases), Ecuador (the Occidental Petroleum case) and Australia (the Philip Morris case).

59 Compare WW Park, 'Arbitrator Integrity' in Waibel et al (eds), The Backlash Against Arbitration 189 (Kluwer 2010) 189-251 - with a number of sub-issues.

60 See Feldman (M Feldman, 'Investment Arbitration Appellate Mechanism Options: Consistency, Accuracy, and Balance of Power' (2017) 32 ICSID Review 528-544), raising also the need to evaluate all competing policy interests.

61 Compare R H Kreindler 'Parallel Proceedings: A Practitioner's Perspective' in M Waibel et al (eds), The Backlash Against Investment Arbitration (Kluwer, 2010) 127 and A Reinisch 'The Issues Raised by Parallel Proceedings and Possible Solutions' in M Waibel et al (eds), The Backlash Against Investment Arbitration (Kluwer, 2010) 113-114. 


\section{ARE PROPOSED ALTERNATIVES AN ADEQUATE REPLY TO THE WEAKNESSES OF INVESTOR-STATE ARBITRATION?}

While many of the critical arguments against ISDS may have some foundation, there is, in my opinion, a sufficient number of reasons which speak against the radical dismantling of the system of international investment arbitration. There may be some periods in the future when more control and more transparency is needed, but in the current political discussions which are generally negatively coloured, at least in the European Union, one should not forget the arguments in favour of investment arbitration, as well as the weaknesses of the alternative options.

In the current 'change of tide', the pendulum has swung back to the other side: while until about a couple of decades ago a polished, overly laudable picture of investment arbitration prevailed, the current criticisms show how short the way from euphoria to hysteria might be. Policies of international trade and their dispute settlement mechanisms may be an important topic, but when they attract disproportionate public attention, populist arguments start to cast a shadow over real problems. Is it actually true that ISDS in general has to be abolished, because it 'threatens public welfare' and 'undermines democracy' - to quote assertions from a public campaign conducted under the slogan 'End corporate courts now!'? To what extent is it correct that ISDS 'undermines environmental standards, prevents regulation or pockets taxpayers' money'? ${ }^{2}$

Leaving the assessment of more serious criticisms for later, we should first address some widespread prejudices regarding investment arbitration which, although untrue, play an important part in framing the negative picture of ISDS in the public eye.

The first prejudice relates to a supposed general bias of the ISDS in favour of investors and against the host states, and the opinion that the majority of investment arbitrations end with awards in favour of the investors. ${ }^{63}$ While in regular litigation it may be expected that slightly more claimants win than lose (starting litigation is, after all, not a step that is undertaken easily and without good cause), according to the UN-collected data the situation with ISDS is different - significantly more cases are decided in favour of the defendants. So, according to an UNCTAD survey, in the 1987-2017 period, 28 per cent of cases were decided in favour of the investor, and 37 per cent in favour of state parties ( 23 per cent are settled, and 10 per cent are discontinued) ${ }^{64}$

62 Statements by the spokesmen of the Stop TTIP alliance Karl Bär, $<$ https://stop-ttip.org/europeansdont-want-investor-state-dispute-settlement-trade-agreements/> accessed 22 February 2019; see also <https://www.usw.org/get-involved/rapid-response/AFLCIO_ISDS_No_Corporate_Courts. pdf $>$ accessed 22 February 2019.

63 See answers in the European Commission ISDS Public Consultation (n 18) 15.

64 UNCTAD ISDS Review (n 9) 6 . The success of the states is often the result of the tribunals finding lack of jurisdiction. Counting only decisions on the merits, $61 \%$ of cases are decided in favour of the investor, and $39 \%$ in favour of the state (ibid). See also on this point C Brower, J Ahmad, 'From the Two-Headed Nightingale to the Fifteen-Headed Hydra: The Many Follies of the Proposed International Investment Court' (2018) 41 Arbitration International 818 (speaking about the need to 'separate facts from fiction'). 
The impact of the ISDS on state regulatory policies (an argument that has played a prominent role in the new anti-ISDS wave in the EU) seems to be grossly exaggerated and partly misunderstood. There is not enough independent research regarding the extent of the impact of the ISDS arbitrations on state regulatory policies.$^{65}$ Still, the percentage of the arbitral decisions which have an impact on state policies is proportionately small. According to available information, many other issues related to host state conduct have given rise to ISDS claims, such as unfair domestic court judgments, illegal contract terminations, alleged nationalisations and imposition of discriminatory taxes. ${ }^{66}$ And, while some regulatory issues have a legitimate public policy grounds (for instance health concerns or environmental protection), others may just be an attempt by the state to indirectly expropriate foreign investors - and to that extent present exactly the kind of cases for which the whole system of ISDS was developed.

Another criticism related to ISDS arbitrators addresses the lack of diversity. ${ }^{67}$ One of the points raised is the small number of female arbitrators in comparison to their male counterparts. Admittedly, this is to a degree true, but one should not forget the fact that the choice of arbitrators is up to the parties, so that the result reflects their preferences. ${ }^{68}$ And, according to UNCTAD data on the most frequently appointed ICSID arbitrators, though there are only two women among the thirteen people listed, they are among the most sought-after arbitrators, occupying number one and number three on the list of the most appointed investor-state arbitrators. ${ }^{69}$ If it is argued that this is still too small a number, these figures should be compared with the higher level international institutional tribunals, such as the WTO Appellate Body, where male members also make up the vast majority, in spite of the fact that they are appointed by bodies which can consciously implement pro-diversity policies. ${ }^{70}$

Leaving aside the prejudices regarding ISDS, we should return to the basics: why arbitration was in the first place preferred as the method of international dispute resolution in the field of international trade, be it regarding the 'pure' commercial disputes between private companies, or in cases in which states participate as parties. There is still some value in the statement that arbitration is good for international

65 For some, but still insufficient attempts to deal with the investment treaty from the perspective of political economy, see Bonnitcha,Poulsen, Waibel (n 54).

66 Compare information on individual cases, eg in UNCTAD reviews.

67 See Polonskaya (n 57).

68 Thus, to the extent that it exists, the lack of diversity would not be attributable to the ISDS mechanisms as such, but to the 'glass ceiling' of the elite business communities and their legal representatives. As noted by Baetens (F Baetens, 'The Rule of Law or the Perception of the Beholder? Why Investment Arbitrators Are under Fire and Trade Adjudicators Are Not: A Response to Joost Pauwelyn' (201516) 109 American Journal of International Law Unbound 304), 'The higher diversity of WTO panelists versus ICSID arbitrators is indeed apparent in the relative proportions of panelists from developing countries and women - although a cynic might remark that the less prestigious a job is, the more likely it is that women and non-Westerners do it.'

69 Brigitte Stern is the most frequently appointed ICSID arbitrator with 87 appointments, and Gabrielle Kaufman-Kohler is in third place, with 49 appointments, after Yves Fortier with 51 (UNCTAD data, ibid 6).

70 See WTO, 'Appellate Body Members' <https://www.wto.org/english/tratop_e/dispu_e/ab_ members_descrp_e.htm> accessed 22 Februar 2019. In the past, the number of women on that body was: 0 out of 7 (in 2001) to 1 out of 7 (in 2018). 
trade, ${ }^{71}$ not only because the UN General Assembly 'recognizes the value of arbitration as a method of settling disputes arising in the context of international commercial relations' and is convinced that the establishment of good rules in that field 'contributes to the development of harmonious international economic relations. ${ }^{72}$ The existence of arbitration options was in the years of the Cold War, but also later, a de facto necessity in order to maintain some form of international trade among economic players from rather different and often mutually rather hostile political environments. Though not perfect, the practice of international commercial arbitration effectively granted legal protection to countless foreign companies, and thus encouraged their willingness to invest and make trade deals in the countries with unstable and unfamiliar legal systems. Has so much changed since the 1980s, when the UNCITRAL Model Law was enacted, in terms of removal of disparities between national laws, greater confidence of the business community in local courts in foreign jurisdictions or the need to find a neutral, unbiased forum in which to overcome differences and settle disputes?

Indeed, one could argue that the current political rage against the ISDS is limited to arbitration options in the BITs and the other forms of treaty-based arbitration that are not expressly grounded on arbitration agreements which are otherwise regarded as the 'cornerstone of arbitration'. Can the dusk of the ISDS be the new dawn of more conventional arbitration options? Some authors have already started to promote agreement-based arbitration alternatives, eg International Chamber of Commerce (ICC) arbitration, as the dispute resolution methods superior to the treaty-based ISDS. ${ }^{73}$ Unfortunately, it seems that the snowball-effect has already started, with the anti-ISDS stance growing ever larger and taking on an increasingly anti-arbitration attitude. For instance, while many arbitration practitioners (and several arbitral tribunals in concrete cases) hold that the Achmea judgment of the CJEU has to be limited to BITs, the European Union makes it increasingly clear that it wishes to stretch the effects of this decision as far as possible. In its statement of 15 January 2019, 22 EU Member States declared that they consider intra-EU BIT and ECT claims to be non-arbitrable and warned the 'investor community' not to initiate new intra-EU investment arbitration proceedings. ${ }^{74}$ The general policy of the EU is already clearly oriented not only against the ISDS (both in intra- and in extra-EU investment disputes), but also against arbitration in general. At least some of the loudly voiced criticisms of the ISDS can equally be applied to customary forms of international commercial arbitration, such as the lack of appeals, the confidentiality of the proceedings and the possible impact that the party appointment can have on the impartiality of the arbitrators. In any case, it is hardly imaginable that in the present climate any EU Member State would lead a pro-arbitration policy, actively

71 Compare JM Mustill, 'Arbitration: History and Background' (1989) 6 (2) Journal of International Arbitration 50.

72 See UN Resolution 40/72 adopted at the 112th plenary meeting on 11 December 1985 (adopting the UNCITRAL Model Law on International Commercial Arbitration).

73 See eg in this sense HG Gharavi, 'The Advantages of the ICC over ICSID in Investment Arbitrations' in A Carlevaris, L Lévy, A Mourre, E Schwartz (eds), International Arbitration Under Review. Essays in honour of John Beechey (ICC Publication 772E 2015).

74 See Declaration of the Member States of 15 January 2019 on the legal consequences of the Achmea judgment and on investment protection, <https:/ec.europa.eu/info/publications/190117bilateral-investment-treaties_en> accessed 22 February 2019. 
encouraging the insertion of arbitration clauses into business contracts concluded between the state (or any of its state agencies) and the foreign private parties. From the suspicious attitude towards arbitration in state-related commercial disputes to a suspicion against (international) commercial arbitration in general is only a few small steps - and this is why the current ISDS debate can also have a long-term negative effect on the use and development of arbitration and ADR in general. ${ }^{75}$

Turning back to the conventional wisdom that arbitration is good for international trade (the wisdom so far most effectively spread and promoted by UNCITRAL), it would follow that the consequences of current developments may mark the beginning of a chilling period for international investments ${ }^{76}$ - unless a new system is established that could effectively replace the protection of investments provided by the current ISDS options and international commercial arbitration in general. Is such a system found?

The EU Member States, in their recent declaration, emphasised that investors from one EU Member State do not need additional protection when they invest their capital in any other Member State, since the fundamental freedoms of the Union, such as freedom of establishment or the free movement of capital, are protected by EU law. ${ }^{77}$ It is also argued that non-discrimination, proportionality, legal certainty and the protection of legitimate expectations belong to the general principles of EU law, which all EU Member States must recognise and provide effective legal protection to intra-EU investors in case of violation of their rights. ${ }^{78}$ However, even in their joint declaration the EU Member States do not argue that such an effective legal (and in particular judicial) protection does exist everywhere in Europe, but only that EU law obliges every Member State to ensure such protection before its courts or tribunals. In reality, the comparative data on European judicial systems show that the narrative about the effective protection is deceptive, as effectiveness of judicial protection is still among the most problematic issues in a number of EU Member States. The situation in this respect is partly deteriorating, as attacks on judicial independence have started to reoccur in several former transition countries. ${ }^{79}$ Even when the state courts operate independently, the excessive length

75 The turn in the approach to arbitration can be felt even in the work of UNCITRAL, where, according to the observers, the methods of work and approach to arbitration are no longer 'business as usual'. Compare A Roberts, 'UNCITRAL and ISDS Reform: Not Business as Usual' [2017] European Journal of International Law, Blog TALK <http://ejiltalk.org/uncitral-and-isdsreform-not-business-as-usual/> accessed 21 February 2019.

76 Some observers predict that current policies will especially have a negative effect particularly on smaller investors, which will either not invest at all, or will convert the costs of the higher risk factor into higher costs and expenses; the large corporations, on the other hand, may have sufficient bargaining strength to impose dispute-settlement provisions which will be even more favourable to them. Compare Brower, Ahmad (n 64) 819-820.

Declaration of the Member States of 15 January 2019, cit at 2.

78 Ibid.

79 Compare the data on European judicial systems of the CEPEJ <http://www.coe.int/cepej> accessed 22 Februar 2019, as well as the information collected in the European Judicial Scoreboards <https:// ec.europa.eu/info/policies/justice-and-fundamental-rights/effective-justice/eu-justice-scoreboard en> accessed 22 February 2019. For attacks on the judiciaries in Hungary and Poland see reports of the Helsinki Foundation for Human Rights <https:/www.helsinki.hu/wp-content/uploads/ Attacking-the-Last-Line-of-Defense-June2018.pdf> accessed 22 February 2019 and the Human Rights Watch; see also <https://euobserver.com/opinion/143624> accessed 22 February 2019. 
of judicial proceedings can render legal protection illusory, as often confirmed by the judgments of the European Court of Human Rights. The court cases including substantive foreign investments are often highly sensitive and politicised, and can be a serious challenge for quite a few European national judiciaries. All that is very well known by potential investors. ${ }^{80}$ It is not accidental that for any serious lawyer the notion of 'litigating international investment disputes' is synonymous with investment arbitration. ${ }^{81}$

In the context of extra-EU trade relations, the EU refrained from using the argument that an investor-state dispute resolution mechanism is unnecessary due to adequate protection at local courts. Instead, since 2010 it gradually started to advocate a more institutional system of dispute settlement, with quasi-permanent arbitrators, appellate mechanisms and increased transparency of the proceedings. ${ }^{82}$ Until 2014, this 'movement away from current ad hoc arbitration' further grew and became the policy of promoting an 'investment court system' (ICS) or a 'multilateral investment court' (MIC). In its 2015 Concept Paper, the European Commission declared the need for 'a new EU approach' and referred to the institutional set-up of the WTO Appellate Body as a model for reform. ${ }^{83}$ According to analysts, it is too early to say what level of support the EU vision of such a multilateral investment court will have, but it is certain that the debate in international fora has been steered in the direction of such a proposal, which is 'a game changer with potentially far-reaching consequences for investment treaty arbitration. ${ }^{34}$

These are important reasons for closer examination of the feasibility of an investment court, promoted as 'a panacea that would solve most, if not all, the perceived shortcomings of the current ISDS system. ${ }^{85}$ Can it really solve the problematic issues? If adopted, will it bring improvement, satisfy the critics and award adequate protection to investors? Many (too many) elements of such a future system are unknown, but there are already sufficient grounds for concern regarding some fundamental elements of the existing MIC proposals.

Starting with the sources of such proposals, it should be noted that they have not originated from the circles of experts in international commercial dispute resolution, but from the Brussels administration which has not much experience with the concrete problems encountered in the course of complex international commercial litigation. The problematic appeal of the proposed solution lies in its simplicity replacing the ad hoc arbitration tribunal with a permanent court - but this simplicity

80 An UNCTAD study shows that investors considered the existence of a BIT rather important when deciding on making investments in a foreign jurisdiction. See C Brower, S Blanchard, What's in a Meme? The Truth about Investor-State Arbitration: 'Why it Need Not, and Must Not, Be Repossessed by States', 52 Columbia Journal of Transnational Law, 52 (2014)704.

81 See the title of a guide edited by C Giorgetti, Litigating International Investment Disputes (Leiden/ Boston, Brill-Nijhoff 2014)), covering the practice of investment arbitration.

82 Lavranos (n 12) 43.

83 European Commission Concept Paper, 'Investment in TTIP and beyond: the path for reform', $<$ http://trade.ec.europa.eu/doclib/html/153408.htm> accessed 22 February 2019.

84 Lavranos (n 12).

85 Ibid. 
can be misleading. The underlying assumption is that a permanent court can render the same, if not better, services as an international arbitral tribunal. But, references to the WTO Appellate Body as a source of inspiration demonstrate a disregard of its fundamental difference. The title of an article published by Joost Pauwelyn in 2015 clearly indicates the extent of the difference, asking, 'Why Investment Arbitrators Are from Mars, Trade Adjudicators from Venus?? ${ }^{86} \mathrm{He}$ argues that two closely related subjects of global economic affairs - cross-border trade and cross-border investment have developed into two distinct parallel worlds, and finds a part of the reasons for this cleft in the rather different nature of WTO adjudicators in comparison with the arbitrators who deal with the ISDS. This analysis is not isolated: already in 2001, Joseph Weiler was writing about the WTO dispute settlement mechanisms in terms of the 'rule of lawyers' versus the 'ethos of diplomats', warning that, in spite of the juridical nature and mandatory character of the WTO dispute resolution system the institutional setting remained much the same as in the times of GATT, reflecting more diplomatic than legal considerations. ${ }^{87}$ While this diplomatic stance of the WTO may make its dispute resolution system 'more palatable and easy to digest' for internal players - primarily the states - the author argues that at times this practice 'accounts for some serious dysfunctions of dispute settlement system' and undermines its external legitimation. ${ }^{88}$ Almost twenty years later, new research shows that nothing has changed in the two worlds: the WTO panelists 'continue to be predominantly diplomats or ex-diplomats, often without law degrees and mostly with relatively little experience, while the ICSID arbitrators by contrast 'are typically high-powered, elite jurists with a much deeper level of expertise and experience than the average WTO panelists. ${ }^{89}$

Evaluated by strictly legal standards, this difference indicates that a WTO-modelled investment tribunal would in most ISDS cases render a decision of lower and not higher quality. The complex nature of international commercial disputes, particularly in the context of substantial investments and transfers of technology, calls for special competence of the decision makers. Most investor-state disputes are highly sophisticated, both legally and technically, and need specialist knowledge in the respective field. Whether they relate to green-field investments or to privatisation of state assets in key fields like energy or mining, whether they relate to industry or to investments into national infrastructure such as roads or airports, the efficient processing of such cases which conforms to the rule of law standards is an immense task. Its challenges are both efficiency and quality - and for meeting these challenges one needs a lot of skill, experience and knowledge. The practice of investor-state arbitrations managed to live up to the expectations of (most) parties: the boom in ISDS has been indirectly a confirmation of its efficiency.

86 J Pauwelyn, 'The Rule of Law Without the Rule of Lawyers? Why Investment Arbitrators Are from Mars, Trade Adjudicators from Venus' (2015) 109(4) American Journal of International Law 761805 doi:10.5305/amerjintelaw.109.4.0761 (2015).

87 JHH Weiler, 'Rule of Lawyers and the Ethos of Diplomats' (2001) 35(2) Journal of World Trade 35(2)191-207. His position is summarised in the statement that '[t]he diplomatic ethos which developed in the context of the old GATT dispute settlement tenaciously persists despite the much transformed juridified WTO/ Ibid 193.

Ibid.

89 Pauwelyn (n 86) 763 
Naturally, ISDS proceedings are not short, and sometimes two, three or four years are needed to complete the process. The length of the ISDS proceedings is, however, caused by the need to undertake comprehensive examination of technical and legal issues, not by attempts to delay the process or by sloppy case management. In fact, there is hardly any other method of dispute resolution capable of dealing with such complexity and sophistication while maintaining strict legal standards of due process. Huge arbitration cases really need a tailor-made court, and the full-time work of arbitrators selected for the particular case. And there may be only a few people in the world capable of effectively dealing with certain complex and specialised issues. Such people have to be paid accordingly, also in a certain proportion to the huge responsibility which they bear and the impact that their decisions produce. It is hard to apply any salary-based model for adjudicators in this context, especially if the salary is determined by the lump-sum criterion, and awarded as side-remuneration to a part-time judge. The same goes for standardised procedures and methods of case management. The "one size fits all" solutions which provide fixed case management rules may be entirely inapplicable when a case involving hundreds of thousands of documents, dozens of experts and witnesses, with huge implications locally and globally. The eventual availability of appeals brings further challenges for the duration of the process and its effectiveness.

The proposed solutions for the challenges of effectiveness and quality of the future MIC have so far not showed that their authors understand (or care about) practical details. In the draft Chapter on Investment Court System in the European Commission draft text of TTIP, the instructive time limits are fixed: 18 months for the issuing of a provisional award ('decision in the first instance') and 180 (or a maximum of 270) days for the duration of the appeal procedure..$^{90}$ There is, however, no guarantee that these limits are anything but a political declaration, and in any case they seem to be quite unrealistic for actual investor-state disputes, if they are to be conducted according to high professional standards.

Apart from the concerns regarding its effectiveness, there may be serious concerns regarding the integrity of the process. The criticisms of the customary ISDS mechanisms often relate to the asymmetric nature of the choice of forum, arguing that investors have disproportionate powers since only they may choose the forum which suits them. ${ }^{91}$ Yet, the asymmetric right to choose the forum and have a recourse to the selected (arbitration) tribunal can to a large extent be justified by the asymmetric power that parties possess, and the potentially vulnerable position of the investors when faced with the court system of the host country. On the other hand, there would be no appropriate justification for the system which would favour the state as the stronger party - and still the proposed MIC solution does have some elements which may have exactly that effect.

The first element that should be observed is the potential bias in favour of the states in the selection of the adjudicators. A good example is the WTO dispute resolution process which was cited by the EU in a positive light as the system according to

$90 \quad$ See Ch II - Investment, Arts 28(5) and 29(3).

91 On such arguments (and their validity) see Brower, Blanchard (n 80) 712. 
which future permanent investment bodies should be modelled. As observed in 2001 by Joseph Weiler, no matter how much the GATT dispute resolution process got 'juridificated', in this process the 'diplomatic ethos ... tenaciously persists. ${ }^{92}$ The panelists of the standing WTO dispute resolution tribunals were often diplomats or ex-diplomats who belong to the same internal WTO network, often without law degrees and with relatively little experience $e^{93}$ - something that Weiler regarded as only a temporary feature. Fifteen years later, Pauwelyn concluded that this structure is not changing, arguing that a part of the success of the WTO dispute resolution process is to be attributed to the fact that it is run by relatively inexperienced trade diplomats. ${ }^{94}$ While it may be true that the diplomatic elements and a degree of political participation by governments and civil society organisations help in legitimising the dispute resolution process, one should not forget that the WTO dispute resolution process is a state-to-state process where both parties stand on equal footing. If, as provided by CETA, an investor-state dispute is decided by the members of the tribunal who 'shall have demonstrated expertise in public international law' (and only optional knowledge of international investment law), ${ }^{95}$ ie by WTO-like former diplomats who have spent their lives representing the interests of the state, it may be legitimately doubted whether these panels have a built-in bias in favour of state parties.

This assessment of bias is not dependent on the nationality of the tribunal members of the present and future 'investment courts'. Indeed, the concrete tribunals will be chaired by a third-party national, and one of the tribunal members will have to be appointed from a jurisdiction close to the investor party. ${ }^{96}$ But, lacking a business perspective and experience, it is likely that those part-time tribunal members who were appointed to a closed list of adjudicators assembled by a joint committee appointed by (state) parties (for CETA: by Canada and the EU) will give a disproportionate weight to the political and not the legal aspects of the case. Unless political arguments strongly speak in favour of the investor as the private party to an investor-state dispute (eg due to the investor's close connection with the state party that upholds a pro-investor policy), there is arguably much less leverage on the investor side than on the state side. Thereby, the partisan nature of appointment of decision makers of conventional investor-state arbitration, which has been cited as the 'single most undermining factor of the public trust in the ISDS system, ${ }^{97}$ is in the architecture of the 'permanent investment tribunals'

92 Weiler (n 87) 763 .

93 Research for the 1995-2009 period showed that $80 \%$ of WTO panelists have a government background (compared to $76 \%$ of ICSID arbitrators who have a private sector background, not counting academics). Pauwelyn (n 86) 772. Baetens (n 68) at 304 points to the fact that a similar problem relates to both ICSID and the WTO: 'Closed and elitist networks are omnipresent in both systems - how else would one describe a system in which nearly two out of every three adjudicators was at some point a Geneva-based diplomat?'

94 Pauwelyn (n 86) 764.

95 See Art 8.27(4) CETA.

96 Compare Art 8.27(6) CETA. Note that, under CETA, for disputes initiated by European investors the 'investor's' member can come from any EU state, which may further diminish the level of participation of views close to its side. 
replaced by another sort of partisanship marked by a structural bias of the onesided appointments by state (or state-like) organisations. ${ }^{98}$ Essentially, while in the present model of investor-state arbitration each side, the investor and the state, has at least the same chance to make partisan appointments, the future model of investment tribunals displays even more troubling, unilateral partisanship. ${ }^{99}$ The attempts to explain that a multilateral court system in which states only appoint judges need not necessarily be biased since states act in dual roles (as disputing parties and treaty parties) and are able to distinguish their functions in a proper way ${ }^{100}$ seem to be overly academic and factually unrealistic, taking into consideration the background of the whole ISDS discussion and the concrete cases outlined here above.

This partisanship is even more evident in the light of the structural influence that is exercised in the future model by administrative officials ${ }^{101}$ involved in the institutional framework of dispute resolution bodies. When the adjudication is entrusted to those that have less experience, and in-depth knowledge will be 'more amenable to being led by a Secretariat', 102 this may be reinforced by the 'embeddedness in a thicker normative/bureaucratic regime or community. ${ }^{103}$ All this will certainly not help in the creation of trust of the investors in the new ISDS model. As if this were not enough, in the current European model of 'investment courts', there are also several other potentially troubling elements, such as the possibility of discretionary rejection of 'claims manifestly without legal merit' upon application of the respondent state, ${ }^{104}$ rules excluding investment tribunals' jurisdiction to review the legality of the state measures

98 It may be argued that the partisan appointments mutually abrogate the partisanship, unless one of the parties is not sufficiently informed or skilful. The same is true for other, legitimate procedural strategies and tactics. Generally, it seems that a part of the initial low success rate of some states in investor-state arbitration can be attributed to the lack of serious preparation for the representation of state interests in the context of an international arbitration. The strategic decisions in the arbitral proceedings on the state side were often done at a political level, without sufficient legal expertise and without proper representation. The states often save money on their lawyers and fail to attract the best legal minds to their legal teams. Those states which have formed their teams of specialists for the ISDS (Argentina for example) turned out to be much more successful in protecting the legal position of the state in the process.

99 Compare for a similar assessment Brower, Blanchard (n 80). See also S Schwebel, 'The Proposals of the European Commission for Investment Protection and an Investment Court System' (ISDS BLOG 17 May 2016) <http://isdsblog.com/wp-content/uploads/sites/2/2016/05/ THEPROPOSALSOFTHEEUROPEANCOMMISSION.pdf> accessed 21 February 2019. According to Schwebel, the fundamental objection to the new investment court system is that it replaces 'the current system, which on any objective analysis works reasonably well, with a system that would face substantial problems of coherence, rationalization, negotiation, ratification, establishment, functioning and financing.

100 See eg A Roberts, 'Would a Multilateral Investment Court be Biased? Shifting to a Treaty Party Framework of Analysis' (EJIL: TALK! 28 April 2017) <https://www.ejiltalk.org/would-amultilateral-investment-court-be-biased-shifting-to-a-treaty-party-framework-of-analysis> accessed 21 February 2019.

101 Baetens refers to an '... invisible back-row of adjudicators who are not accountable, whose names are not on the report, whose personal conflicts need not be disclosed, but who may nevertheless exert influence on the decision. Ibid at 306.

102 Ibid.

103 Pauwelyn (n 86) 796.

104 CETA, Art 8.32. 
and their obligation to follow the 'prevailing interpretation of the domestic law' by its 'courts or authorities.' ${ }^{105}$

\section{CONCLUDING REMARKS}

Challenges are generally healthy for future development, if we manage to survive them. Nietzsche's famous 'What doesn't kill me makes me stronger' may also be applied to investment arbitration. Only, the prospects for investor-state arbitration surviving in the short and medium run as the dominant method of investor-state dispute resolution are far from certain, at least as regards the European Union and its Member States.

Before the Eurocrats put the final nail in the coffin of the ISDS, just how likely it is that the alternative offered will be better than the existing options should be thoroughly examined. So far, the ISDS has played an important role in the global fostering of international investment, by securing a basically fair system of dispute resolution in a very specific field. Of course, no system is perfect, and it is true that investor-state arbitration has proved to have certain shortcomings. At the same time, it is far from having been proved that the shortcomings are of such a nature that they render the whole ISDS mechanism beyond repair.

In this paper I have showed that many criticisms of the ISDS are misguided or overstated, and that the current fuzzy contours of the 'multilateral investment courts' (MIC) - a mechanism which should replace the ISDS - do not guarantee cure for its faults. While the basic criticisms related to lack of impartiality, openness and diversity have not been resolved beyond doubt in the MIC model, new issues related to efficiency, fairness and quality of the new model are appearing. Also, while the new model fails to prove that it is encouraging for foreign investments, the dismantling of the ISDS may have a chilling effect on international commercial arbitration, and, in consequence, may adversely impact international trade.

The negative impact on international arbitration does not mean a positive impact on (international) litigation. National courts will not become a better place for the settlement of international commercial disputes if the use of arbitration fades away. On the contrary, a politically-coloured adjudication process like the one which is likely to develop under MIC may provide the wrong role model for the commercial courts of the host countries. From the perspective of civil procedure, an argument for reconsideration of the current hostility towards investment arbitration may be in the contribution of international arbitration to innovation in dispute resolution. The innovation is visible in the ability to introduce the most modern - and most appropriate - case management techniques, adjusted to the nature of each case, and in the ability to create ad hoc structures which can cope with the most complex factual and legal issues in an increasingly complex world. Some of such innovations have later been exported to the area of state justice, where they have been used by the courts, judges and parties. They also inspired legislative changes that have improved

105 CETA, Art 8.31. 
civil procedures worldwide. ${ }^{106}$ By introducing innovations developed and tested in the field of international commercial arbitration, we have not only an opportunity to build a better system of civil justice, but also an opportunity to achieve greater harmonisation in the field of dispute resolution on a global level.

On this background one should evaluate the future steps in the reforms of the ISDS. Some scholars have already catalogued the alternative avenues of change, and labelled them as incremental, systemic and paradigmatic reforms. ${ }^{107}$ Yet, according to the description of the three models, ${ }^{108}$ something seems to be missing: a fundamental reform which goes beyond modest cosmetic changes in the outlook of the investment arbitration, but preserves the specific advantages of arbitration, including its flexibility, its ability to select the best adjudicators for the specific case, its significant degree of party autonomy and its procedural efficiency. This, apparently missing link of fundamental arbitration reforms of ISDS, is the most promising path.

Such fundamental reforms would need to address the fundamental criticisms, such as the issue of transparency (already discussed within UNCITRAL); the concerns regarding the proper balance between the right of the state to regulate in the public interest and the need to secure stability and foreseeability for foreign investments (based on a thorough and impartial research into the real proportions of the problem) and the issue of party appointments as a potential threat to the integrity of the process. Whether appeals would be an element of the reformed ISDS architecture might depend on the outcome of the other reforms. If, indeed, the reforms found an adequate answer for the 'moral hazards' of party appointments, ${ }^{109}$ the addition of appeals - ie of a lengthy and costly process of full review that is a necessary evil if we distrust the original adjudicators - may turn out to be unnecessary.

Yet, whether fundamental but reasonable reforms of the ISDS would take place will ultimately depend on the policy decision. The European Union at present seems to have made up its mind - though we seriously doubt that its current preference is the result of a prudent and thorough study of the problem. The preceding analysis indicates rather that the European anti-ISDS stance evolved due to a mix of diverse elements: political pressures (arising from different sides, from populist politicians to trade unions and NGOs); the selfish interests of particular states that want to avoid enforcing particular arbitral awards, when and if they oblige the states to

106 The practice of combining experts and expert witnesses, the managing of witness evidence, the introduction of procedural calendars and procedural compacts between the court and the parties on the conduct of the proceedings, the time-management techniques (eg distribution of time by chess clock rule): all these methods have been popularised and further developed in the context of international arbitration, and now they contribute to worldwide improvement of civil justice systems.

107 See A Roberts, 'Incremental, Systemic, and Paradigmatic Reform of Investor-State Arbitration' (2018) 112 410-432; see also Puig, Schafer (n 51).

108 According to Roberts, incrementalists only want 'modest reforms' of the ISDS; systemic reformers advocate multilateral investment courts, and paradigm shifters dismiss the existing system entirely, referring to domestic courts or state-to-state arbitration.

109 See Paulsson (n 52); A van den Berg, Dissenting Opinions by Party-Appointed Arbitrators in Investment Arbitration, in: Looking to the Future: Essays on International Law in Honor of W.M.Reisman (Brill 2011). 
compensate particular investors; and the wish of the EU institutions (from the European Commission to the CJEU) to strengthen and reaffirm the powers of the Union regarding trade policies vis-à-vis the Member States. This is not the best basis for the future development in the area of international commercial dispute resolution.

Hopefully, policy decisions can change. If, as predicted, the current anti-ISDS (and anti-arbitration) does not produce beneficial effects, the new turn in the approach to mechanisms of dispute resolution between investors and states will happen sooner or later - hopefully not too late. Consequently, my advice for the policymakers faced with the ISDS dilemma can be summarised in the words of an old proverb: Fix it, don't throw it away! Otherwise, the consequences are likely to be detrimental to the very goals these policymakers wish to pursue. 